University of Nebraska - Lincoln

DigitalCommons@University of Nebraska - Lincoln

September 2003

\title{
Effects of chronic caffeine pre-exposure on conditioned and unconditioned psychomotor activity induced by nicotine and amphetamine in rats
}

\author{
M. I. Palmatier \\ University of Nebraska-Lincoln \\ E. Y. K. Fung \\ University of Nebraska Medical Center \\ Rick A. Bevins \\ University of Nebraska-Lincoln, rbevins1@unl.edu
}

Follow this and additional works at: https://digitalcommons.unl.edu/psychfacpub

Part of the Psychiatry and Psychology Commons

Palmatier, M. I.; Fung, E. Y. K. ; and Bevins, Rick A., "Effects of chronic caffeine pre-exposure on conditioned and unconditioned psychomotor activity induced by nicotine and amphetamine in rats" (2003). Faculty Publications, Department of Psychology. 38.

https://digitalcommons.unl.edu/psychfacpub/38

This Article is brought to you for free and open access by the Psychology, Department of at DigitalCommons@University of Nebraska - Lincoln. It has been accepted for inclusion in Faculty Publications, Department of Psychology by an authorized administrator of DigitalCommons@University of Nebraska - Lincoln. 
Palmatier MI, Fung EYK, \& Bevins RA (2003) Effects of chronic caffeine preexposure on the conditioned and unconditioned psychomotor activity induced by nicotine and amphetamine in rats. From Behavioural Pharmacology, 14, 191-198. Published by Lippincott Williams \& Wilkins; copyright (c) 2003 Lippincott Williams \& Wilkins. Used by permission. 


\title{
Effects of chronic caffeine pre-exposure on conditioned and unconditioned psychomotor activity induced by nicotine and amphetamine in rats
}

\author{
M.I. Palmatier ${ }^{a}$, E.Y.K. Fung ${ }^{b}$ and R.A. Bevins ${ }^{a}$
}

Three experiments examined the effects of chronic preexposure to caffeine on the subsequent conditioned and unconditioned locomotor activating effects of nicotine or amphetamine in rats. Rats were given daily intraperitoneal injections of caffeine anhydrous $(0,10$ or $30 \mathrm{mg} / \mathrm{kg}$ base $)$ for 30 days. Conditioning (environment-drug pairings) began after the last day of caffeine pre-exposure. Preexposure to $30 \mathrm{mg} / \mathrm{kg}$ of caffeine enhanced the acute and chronic locomotor effects of amphetamine $(0.5 \mathrm{mg} / \mathrm{kg})$. A similar enhancement of activity was not seen with the high $(0.421 \mathrm{mg} / \mathrm{kg}$ base) or low dose $(0.175 \mathrm{mg} / \mathrm{kg})$ of nicotine. In a drug-free test, the distinct environment paired with amphetamine and the high dose of nicotine evoked increases in activity relative to controls. Caffeine pre-exposure did not affect expression of this conditioned hyperactivity. These effects of caffeine pre-exposure on amphetamine-induced activity could not be attributed to non-specific effects of caffeine. Behavioural Pharmacology 14:191-198 (C) 2003 Lippincott Williams \& Wilkins.

Behavioural Pharmacology 2003, 14:191-198

Keywords: acetylcholine, adenosine, cross-sensitization, context, dopamine, hyperactivity, Pavlovian conditioning, rat

"Department of Psychology, University of Nebraska-Lincoln and bepartment of Oral Biology, College of Dentistry, University of Nebraska Medical Center, Lincoln, Nebraska, USA.

Sponsorship: This research was supporled by grants from NIH (DA11893), Nebraska Department of Health, the UN-L Research Council, and the UNMC College of Dentistry.

Correspondence and requests for reprints to Rick A. Bevins, University of Nebraska, Department of Psychology, 238 Burnett Hall, Lincoln, Nebraska 68588-0308, USA.

E-mail: rbevins@unl.edu

Received 27 June 2002 Accepted as revised 4 February 2003

hyperactivity) are the unconditioned responses (URs). When these unconditioned drug effects reliably occur in the presence of environmental cues (i.e. conditioned stimuli or CSs), the drug effects and cues can become associated via Pavlovian conditioning processes. For example, in our laboratory, nicotine-conditioned hyperactivity is evidenced as more activity relative to controls in the absence of nicotine but in the presence of environmental cues (context GS) that have been repeatedly paired with nicotine (Bevins at at., 2001; Palmaticr and Bevins, 2002; see Reid et al, 1998 for an alternative testing protocol).

Chronic exposure to one drug might promote increased behavioral sensitivity to another drug (e.g. Vezina et al., 1989; Liguori et al., 1997; Fenu et al, 2000; Beyer et al., 2001; Lamarque et al., 2001; Pontieri et al., 2001; Cauli and Morelli, 2002). In one such study, repeated daily exposure to the dopamine (DA) $\mathrm{D}_{2}$ receptor subtype agonist bromocriptine induced hyperactivity when rats were later challenged with the non-specific adenosine antagonist caffeine or the adenosine $\mathrm{A} 2 \mathrm{~A}$ receptor subtype antagonist SCH 58261, regardless of test environment (Fenu tt $a l ., 2000)$. Of particular interest in the present report is the potential for 'cross-sensitization' between caffeine and other drugs of abuse. Caffeine is prevalent in a wide variety of foods, beverages, and over-the-counter 
medications. Fredholm et al. (1999) estimate that children aged $7-10$ years ingest approximately $0.5-1.8 \mathrm{mg} / \mathrm{kg}$ caffeine/day, primarily from soft drinks and chocolate products. To our knowledge, longitudinal assessment of caffeine as a risk factor for susceptibility to later drug use has not been investigated in humans. However, some studies have identified a relationship between caffeine consumption and use of alcohol or other abused drugs (e.g. Istvan and Matarazzo, 1984; Brown and Benowitz, 1989; Kozlowski et al., 1993). Further, caffeine intake is a potential risk factor for relapse to tobacco use (e.g. Cummings et al., 1985; Krall et al., 2002).

Recent studies using animal models have confirmed these purported observations of cross-sensitization. Gaffeine pre-exposure can enhance the reinforcing (Shoaib et $a l ., 1999)$ and discriminative (Gasior $e t$ al., 2000, 2002) effects of nicotine, as well as the acute psychomotor effects of nicotine, cocaine and amphetaminc (Gasior $e t$ al. 2000). The purpose of the present research was to test the effects of chronic caffeine pre-exposure on the subsequent acute and chronic unconditioned locomotor activity induced by nicotine and amphetamine in rats. Although caffeine pre-exposure might enhance the acute ambulatory effects of amphetamine and nicotine (e.g. Gasior et al., 2000), its chronic effects are unclear. Also, chronic drug exposure might be deleterious to associations formed between drugs and other cues (e.g. Cappel and Poulos, 1979; Iwamoto and Williamson, 1984; Kunin $e t$ al., 1999, 2000; Palmatier and Bevins, 2001; but see Shoaib et al., 1994; Bevins and Palmatier, 2003). Thus, drug (US) pre-exposure in a Pavlovian drug-conditioning situation mighe facilitate or retard acquisition of conditioned associations. Accordingly, we also assessed how chronic pre-exposure to caffeine affects the acquired conditioned association between the context CS and the psychomotor effects of nicotine or amphetamine (i.e. context-dependent hyperactivity).

\section{Method}

\section{Subjects}

One hundred and fifteen naive male Sprague-Dawley rats from Harlan Industries (Indianapolis, Indiana, USA) were housed individually in hanging wire-mesh cages. The rats weighed $150-224 \mathrm{~g}$ on arrival. Food and water were continuously available in the home cage. The colony was maintained on a 12:12 light/dark cycle; all procedures were conducted in the light portion of the cycle. Each rat was handled for approximately $2 \mathrm{~min}$ daily for 3 days prior to the start of the experiment.

\section{Apparatus}

All pre-exposure injections took place in the home cage. Conditioning was conducted in eight cylindrical PVC activity chambers measuring $30.5 \mathrm{~cm}$ in diameter. Each chamber was fitted with two infrared emitter/detector units located $4 \mathrm{~cm}$ above the wire-mesh floor that divided the chamber into four equal sections. Infrared beambreaks were recorded automatically by a personal computer and served as the measure of activity.

\section{Experiment $1 \mathrm{~A}$}

This experiment sought to examine the effects of chronic caffeine pre-exposure on the unconditioned and conditioned psychomotor effects of $0.421 \mathrm{mg} / \mathrm{kg}$ nicotine. In our laboratory, this dose of nicotine produces robust conditioned hyperactivity on a drug-free test for conditioning (Bevins et al., 2001; Palmatier and Bevins, 2002).

\section{Procedure}

Caffeime pre-exposure. At the start of each experiment, rats were randomly assigned ( $n=20$ per dose) to one of three doses of caffeine $(0,10$ or $30 \mathrm{mg} / \mathrm{kg})$. Each rat was injected i.p. with its assigned dose of caffeine once daily for 30 days. Injections occurred in the afternoon $(16.30 \pm 11$ ).

Context-nicotine exposure (conditioning). Rats from each caffeine dose were randomly assigned to one of two conditions (Paired or Unpaired; $n=10$ per condition). Nicotine conditioning began approximately $17 \mathrm{~h}$ after the last caffeine pre-exposure injection (day 31). Paired rats were injected with $0.421 \mathrm{mg} / \mathrm{kg}$ nicotine s.c. immediately before placement in the activity chambers. Unpaired rats were injected s.c. with saline immediately before placement. Conditioning continued once daily for 10 days. Locomotor activity (infrared beam-breaks) was recorded for the entire $30-\mathrm{min}$ conditioning trial. To equate drug exposure, approximately $6 \mathrm{~h}$ after each conditioning trial rats assigned to the Unpaired conditions were given s.c. injections of nicotine in the home cage; Paired rats were injected with saline. This temporal separation produces no evidence of conditioned excitation or inhibition in the Unpaired condition. In fact, this protocol results in an activity profile in the Unpaired condition that is similar to that of rats never exposed to nicotine (see Experiment 2 of Bevins et al., 2001).

Drug-free test for conditioning. Twenty-four hours after the last conditioning trial, rats were given a drug-free test. Prior to placement in the activity chambers for the 30min test, all rats were injected s.c. with saline.

\section{Experiment 1B}

Experiment $1 \mathrm{~B}$ assessed the effects of caffeine pre-exposure on the subsequent unconditioned and conditioned effects of a lower dose of nicotine $(0.175 \mathrm{mg} / \mathrm{kg})$ that has weak locomotor suppressing and activating effects and does not support conditioning (Bevins et al., 2001). Using a lower nicotine dose might reveal unconditioned and conditioned effects of caffeine 
pre-exposure potentially masked by a higher nicotine dose (i.e. ceiling effect).

\section{Procedure}

All experimental procedures were identical to Experiment 1A, except as follows. Based on findings from Experiment $1 \mathrm{~A}$ (see later), only the 0 and $30 \mathrm{mg} / \mathrm{kg}$ caffeine preexposure doses were included in Experiment 1B. Also, the nicotine dose was reduced to $0.175 \mathrm{mg} / \mathrm{kg}$. For each caffeine pre-exposure dose $(0$ or $30 \mathrm{mg} / \mathrm{kg}$ ), eight rats received nicotine immediately before placement in the acrivity chambers (Paired) and seven rats received nicotine in the home cage (Unpaired).

\section{Experiment 2}

Experiment 2 assessed the generality of the results of Experiment $1 \Lambda$ by examining the effects of chronic caffeine exposure on the later psychomotor effects of another stimulant (i.e. amphetamine). Given the diversity of locomotor conditioning protocols with amphetamine (e.g. Stewart ot al., 1994; Ahmed at al., 1996; Bespelov and Zvartau, 1996; Arvanitogiannis et al., 2000; Sutton et al., 2000), we conducted a pilot study to examine amphetamine $(0.125,0.25,0.5$ and $1.0 \mathrm{mg} / \mathrm{kg})$, using the conditioning protocol described for nicotine. Mean activity counts for the drug-free test for conditioning (11th session) are presented in Table 1. Based on these results, we selected the $0.5 \mathrm{mg} / \mathrm{kg}$ amphetamine dose for Experiment 2 because it supported robust condicioned hyperactivity after 10 rrials (cf. the $0.421 \mathrm{mg} / \mathrm{kg}$ nicotine dose, Experiment $1 \mathrm{~A}$ ).

\section{Procedure}

Caffeine pre-expesure. Pre-exposure was similar to that used in Experiment 1B. During this phase, one animal was removed due to experimenter error. Thus, analyses included 20 rats in the $0 \mathrm{mg} / \mathrm{kg}$ condition and 19 rats in the $30 \mathrm{mg} / \mathrm{kg}$ condition.

Table 1 Experimental conditions and mean ( \pm 1 SEM) activity counts on the drug-free test for activity (11th session) of the pilot experiment

\begin{tabular}{llc}
\hline Amphetamine dose & Group & $\begin{array}{c}\text { Mean }( \pm 1 \text { SEM) aclivity } \\
\text { counts }\end{array}$ \\
\hline $0.125 \mathrm{mg} / \mathrm{kg}$ & Paired $(n=8)$ & $447.60(43.42)$ \\
& Unpaired $(n=8)$ & $328.90(21.72)$ \\
$0.25 \mathrm{mg} / \mathrm{kg}$ & Paired $(n=8)$ & $527.40(53.36)$ \\
& Unpaired $(n=8)$ & $275.90(27.20)$ \\
$0.5 \mathrm{mg} / \mathrm{kg}$ & Paired $(n=8)$ & $591.40(44.33)$ \\
& Unpaired $(n=8)$ & $313.30(23.62)$ \\
$1.0 \mathrm{mg} / \mathrm{kg}$ & Paired $(n=8)$ & $498.80(31.40)$ \\
& Unpaired $(n=7)$ & $318.90(39.91)$ \\
\hline
\end{tabular}

Using a two-way ANOVA the main effect of amphetamine dose $[F(3,55)=1.13, P=0.34]$ and the Group $\times$ Dose interaction $[F(3,55)=1.91$, $P=0,14]$ were not significant. However, there was a significant main effect of Group $[F(1,55)=62.17, P<0.001]$, indicating that Paired rats displayed conditioned hyperactivity relative to Unpaired controls regardless of conditioning dose.
Context-amphetamine exposure (conditioning). Unless mentioned, the procedural details for context-ampletamine exposure were identical to those in Experiments $1 \mathrm{~A}$ and 1B. Paired groups ( $/=10$ per pre-exposure condition) received $0.5 \mathrm{mg} / \mathrm{kg}$ amphetamine i.p. immediately before 30-min exposure to the activity chambers; i.p. saline was administered in the home cage approximately $6 \mathrm{~h}$ later. Unpaired $(0 \mathrm{mg} / \mathrm{kg}$ calfeine, $n=10 ; 30 \mathrm{mg} / \mathrm{kg}$ caffeine, $n=9$ ) groups received similar treatment, except that saline was administered before placement in the activity chambers and amphetamine was given in the home cage.

Drug-free test for conditioning. The 30-min drug-free test was similat to that of Experiments $1 \mathrm{~A}$ and $1 \mathrm{~B}$, except that saline was injected i.p.

\section{Drugs}

Amphetamine hydrochloride and caffeine anhydrous (Sigma, St. Louis, Missouri, USA) were dissolved in saline $(0.9 \% \mathrm{NaCl})$ and injected i.p. at a volume of $2 \mathrm{ml} / \mathrm{kg}$ for caffeine and $1 \mathrm{ml} / \mathrm{kg}$ for amphetamine. (-)-Nicotine hydrogen tartrate salt (Sigma) wals dissolved in saline and brought to a $\mathrm{pH}$ of $7.0 \pm 0.2$ with a dilute $\mathrm{NaOH}$ solution. Nicotine was injected s.c. at a volume of $1 \mathrm{~m}] / \mathrm{kg}$. Doses of caffeine and amphetamine are expressed as the salt form; nicotine doses are expressed as the base form.

\section{Data analyses}

Analyses of variance (ANOVAs) were used for overall comparisons. For example, omnibus ANOVAs including one within-subjects factor, Trial, and two betweensubjects factors, Group (Paired or Unpaired) and Dose (e.g. 0, 10 or $30 \mathrm{mg} / \mathrm{kg}$ caffeine), were conducted as tests for caffeine pre-exposure effects on nicotine- or amphetamine-induced activity. Further, to assess the nonspecific effects of caffeine exposure on activity, data from Unpaired groups were analyzed separately using Caffeine Dose as the between-subjects factor and Trial as the repeated measure. This maneuver provided a more sensitive test for possible non-specific effects of caffeine exposure on activity. Drug-free tests were analyzed with two-way ANOVAs in which Group and Dose were the between-subject factors. A two-tailed rejection criterion $(P \leq 0.05)$ was used for all other analyses.

\section{Results \\ Experiment 1A \\ Non-specific effects of caffeine pre-exposure}

Gaffeine can have anorectic effects. For example, Gans (1984) found that, relative to saline controls, body weight and food consumption were attenuated for rats chronically exposed to caffeine (see also Palmatier and Bevins, 2001). To test this possibility, body weight on the last day of caffeine pre-exposure (day 30) was compared for rats pre-exposed to each dose of caffeine $(0,10$ or $30 \mathrm{mg} / \mathrm{kg})$. 
There were no significant differences in body weight between caffeine doses $[F(2,57)=1.75$, NS $]$.

Figure 1A shows locomotor activity across conditioning trials for Unpaired groups pre-exposed to caffeine or saline. There was a significant main effect of Trial $[F(9,243)=53.59, \quad P<0.001]$, denoting that activity decreased over trials. The main effects of Dose and the Dose $\times$ Trial interaction were not significant $\left[F_{S}<1\right]$, indicating that, in our situation, caffeine pre-exposure did not affect later motor activity in a drug-free state.

\section{Nicotine-induced activity $(0.421 \mathrm{mg} / \mathrm{kg})$}

Omnibus ANOVA examined nicotine-induced activity for the Unpaired and Paired groups across conditioning trials (Figs 1A, B). There were significant main effects of Trial $[F(9,486)=10.08, \quad P<0.001]$, and of Group $[F(1,54)=25.48, P<0.001]$. The Group $\times$ Trial interaction was also significant $[F(9,486)=143.48, P<0.01]$, indicating that, as conditioning progressed, activity for Paired rats increased relative to that for Unpaired controls. The main effect of Dose $[F(2,54)=2.20$, NS $]$ and the Group $\times$ Dose interaction $[F(2,54)=1.91$, NS $]$, the Dose $\times$ Trial and the Group $\times$ Dose $\times$ Trial interactions $\left[F_{\mathrm{S}}<1\right]$ were not significant,

\section{Drug-free test}

Data from the drug-free test for conditioning are presented in Fig. 1C. A two-way ANOVA revealed a significant effect of Group $[F(5,54)=65.79, P<0.0001]$, indicating nicotine-conditioned hyperactivity in the Paired rats. The main effect of Dose and the Group $x$ Dose interaction were not significant $\left[F_{S}(2,54) \leq 2.08\right.$, NS].

\section{Experiment 1B}

\section{Non-specific effects of caffeine exposure}

The body weight of rats on the last day of pre-exposure did not differ significantly across caffeine doses ( 0 versus $30 \mathrm{mg} / \mathrm{kg})[F(1,28)=1.57$, NS $]$. Figure $2 \mathrm{~A}$ shows mean activity counts for the two Unpaired groups. Analyses revealed a significant main effect of Trial $[F(9,117)=7.78, P<0.01]$, indicating that activity in the Unpaired groups decreased over the 10 conditioning trials. The main effect of Caffeine Dose and the Dose $x$ Trial interaction were not significant $[F s<1]$, confirming that chronic pre-exposure to caffeine does not affect motor activity in a non-specific manner.

\section{Nicotine-induced activity $(0.175 \mathrm{mg} / \mathrm{kg})$}

Omnibus ANOVA examined activity for the Unpaired and Paired groups across conditioning trials (Figs $2 \mathrm{~A}$ and 2B, respectively). There was a significant Group $\times$ Trial interaction $[F(9,234)=19.84, P<0.001]$, indicating that over the 10 conditioning trials, activity in Paired groups
Fig. 1

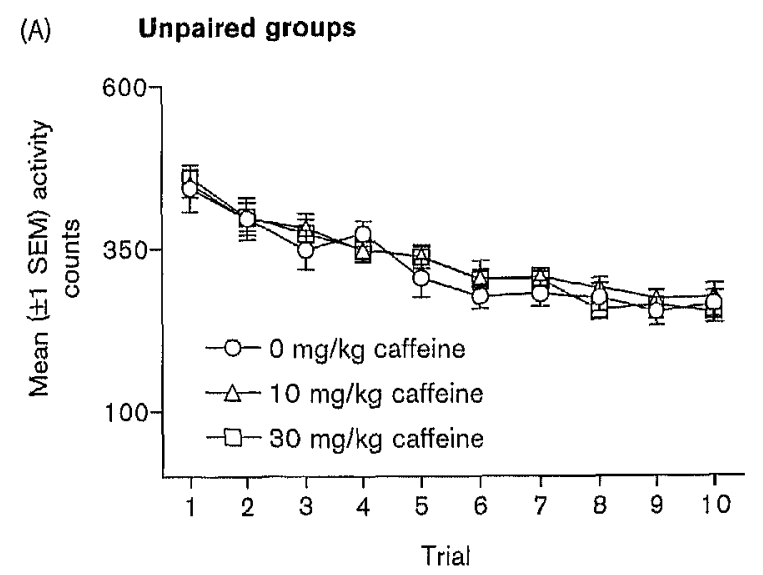

(B) Paired groups

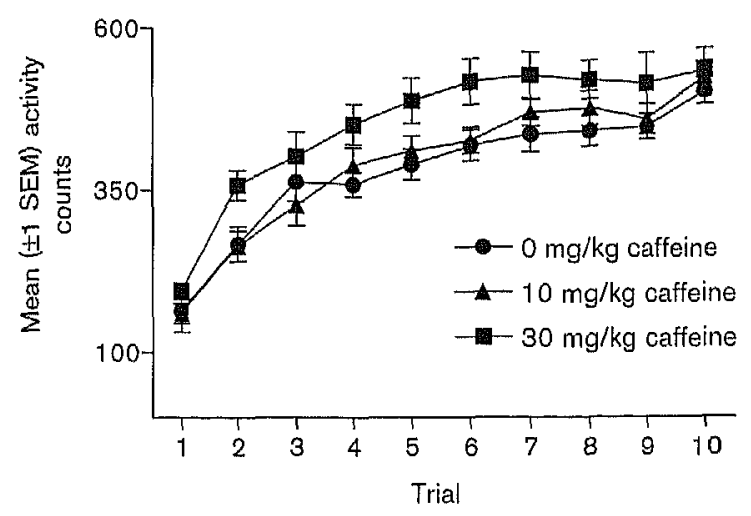

(C) Drug free test

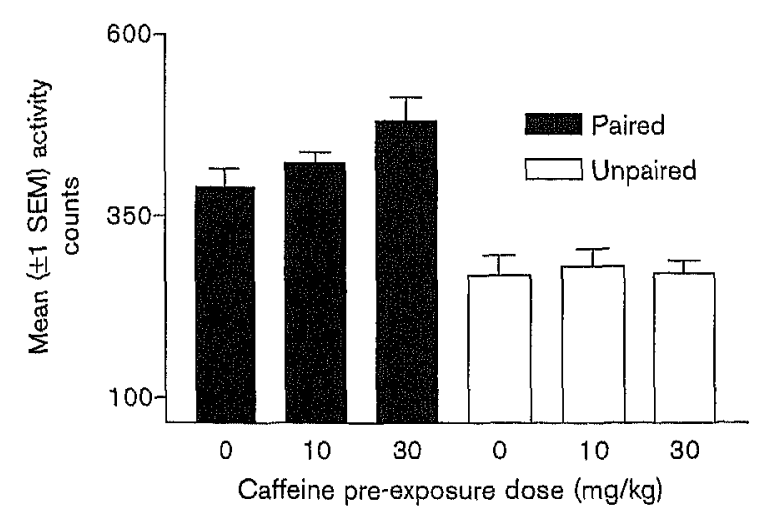

Locomotor activity for rats treated with $0.421 \mathrm{mg} / \mathrm{kg}$ nicotine (Experiment $1 A)$. (A) and $(B)$ contrast caffeine pre-exposure conditions for Unpaired and Paired groups across conditioning trials, respectively. (C) Activity on the drug-free test for conditioning.

increased and activity in Unpaired groups decreased. The main effects of Group, Trial, and Dose were not significant $\left[F_{\mathrm{S}} \leq 2.84, \mathrm{NS}\right]$. The interactions in which Dose $(0$ or $30 \mathrm{mg} / \mathrm{kg}$ ) was a factor were not significant either $\left[F_{S} \leq 1.26, \mathrm{NS}\right]$. 
Fig. 2
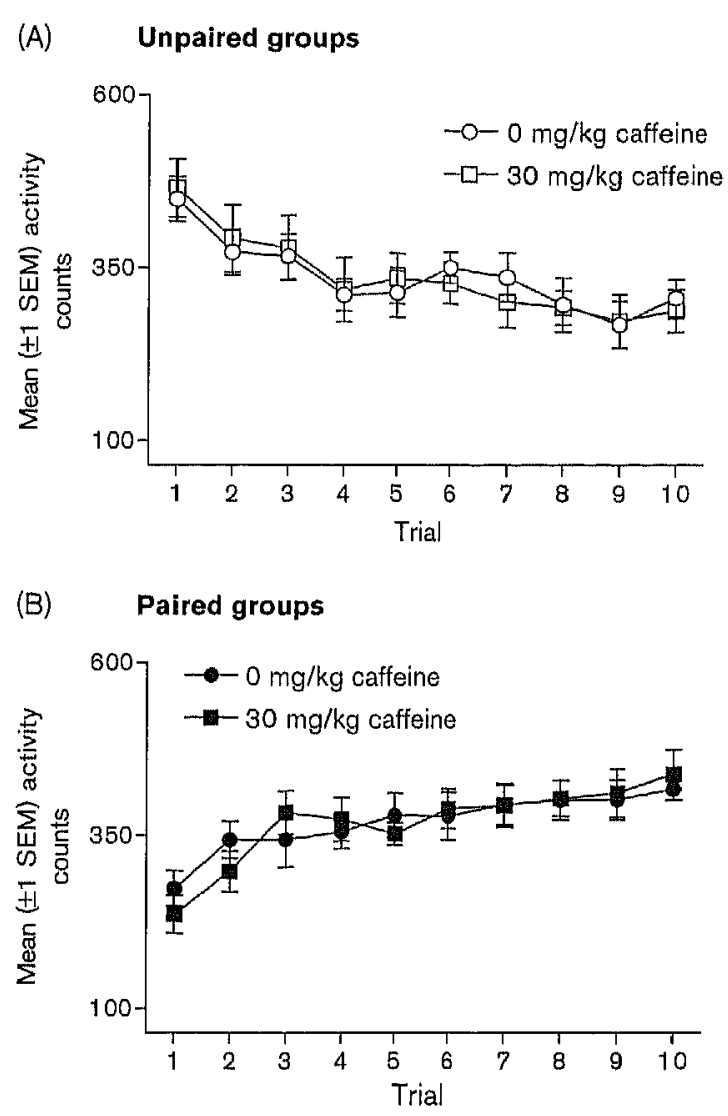

(C) Drug-free test

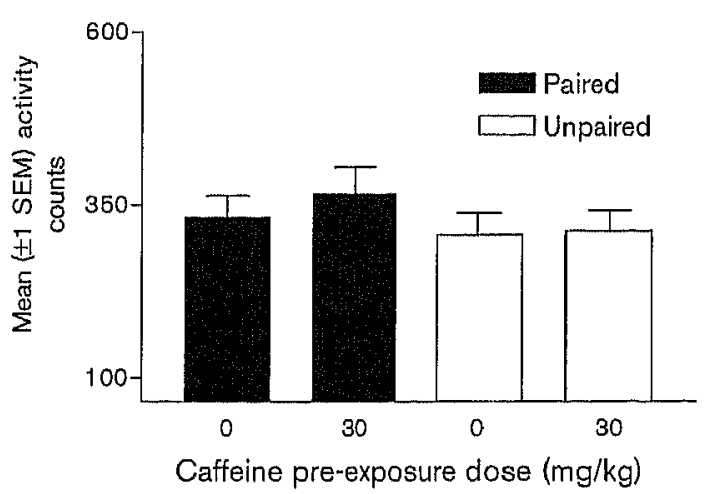

Locomotor activity for rats treated with $0.175 \mathrm{mg} / \mathrm{kg}$ nicotine (Experiment $1 \mathrm{~B}$ ). (A) and (B) contrast 0 versus $30 \mathrm{mg} / \mathrm{kg}$ caffeine preexposure for Unpaired and Paired groups, respectively. (C) Activity data from the drug-free test for conditioning.

\section{Drug-free test}

Figure $2 \mathrm{C}$ shows activity from the drug-free test for conditioning. The two-way ANOVA revealed that the main effect of Group, Dose, and the Dose $\times$ Group interaction were not significant $\left[F_{S} \leq 2.15\right.$, NS $]$. No main effect of Group or Dose $\times$ Group interaction indicates that $0.175 \mathrm{mg} / \mathrm{kg}$ nicotine did not support conditioned hyperactivity in our situation and that caffeine preexposure did not alter this outcome.

\section{Experiment 2}

Non-specific effects of caffeine exposure

As in the previous experiments, caffeine pre-exposure did not alter body weight $[F(1,37)=2.06$, NS]. On the first conditioning trial (day 31) an equipment failure resulted in the loss of data for 13 rats. Therefore, these data were analyzed separately from the remaining trials using a Student's $t$-test (Fig. 3A). For Unpaired rats, there was no difference in activity between caffeine pre-exposure doses on the first conditioning trial $[t<1]$. Repeatedmeasures ANOVA examined possible non-specific effects of calfeine in Unpaired rats on subsequent trials (i.e. 2-10). For the Unpaired groups, there was a significant main effect of Trial $[F(8,136)=3.92, P<0.05]$. The main effect of Dose and the Dose $\times$ Trial interaction were not significant $\left[F_{\mathrm{S}}<1\right]$, indicating that caffeine preexposure did not have a non-specific effect on activity.

\section{Amphetamine-induced activity $(0.5 \mathrm{mg} / \mathrm{kg})$}

Trial 1 data for caffeine pre-exposed (Paired $n=7$, Unpaired $n=6$ ) and non-pre-exposed (Paired $n=5$, Unpaired $n=8$ ) rats were analyzed separately with a two-way ANOVA. Given the decrease in statistical power due to loss of acute amphetamine data, combined with the previous findings that caffeine potentiates activity induced by amphetamine in an acute challenge (Gasior et $a l, 2000)$, statistical significance for this analysis was set at $P \leq 0.10$ (one-tailed). There was a significant main effect of Group $[F(1,22)=12.06, P<0.01]$, and a significant Dose $\times$ Group interaction $[F(1,22)=4.07$, $P=0.056$. The main effect of Dose was not significant $[F(1,22)=2.62, N S]$. Subsequent comparisons prompted by the Dose $\times$ Group interaction examined amphetaminetreated rats (i.e. Paired groups) relative to comparable saline-treated (Unpaired) controls. The comparisons revealed that for non-pre-exposed rats, Paired and Unpaired groups were statistically similar $[t<1]$ (Fig. 3C, Trial 1). However, chronic caffeine pre-exposure potentiated acute amphetamine-induced activity $[t(11)=4.21, P<0.01]$ (Fig. 3D, Trial 1 )

Activity data illustrated in Figs 3C and D contrast Paired and Unpaired groups for non-pre-exposed and caffeine pre-exposed rats, respectively. Omnibus ANOVA for Trials 2-10 revealed a significant main effect of Trial $[F(8,280)=2.75, P<0.01]$, of Group $[F(1,35)=94.01$, $P<0.001]$, and of Dose $[F(1,35)=4.78, P<0.05]$. The Group $\times$ Trial interaction $[F(8,280)=2.90, P<0.01]$ was also significant, indicating that activity in Paired and Unpaired groups diverged across trials. The Dose $\times$ Group interaction $[F(1,35)=4.69, P<0.05]$ was also significant; however, the Dose $\times$ Trial and Group $\times$ Dose $\times$ Trials interactions were not significant $[F s \leq 1.22]$. The main 
Fig. 3
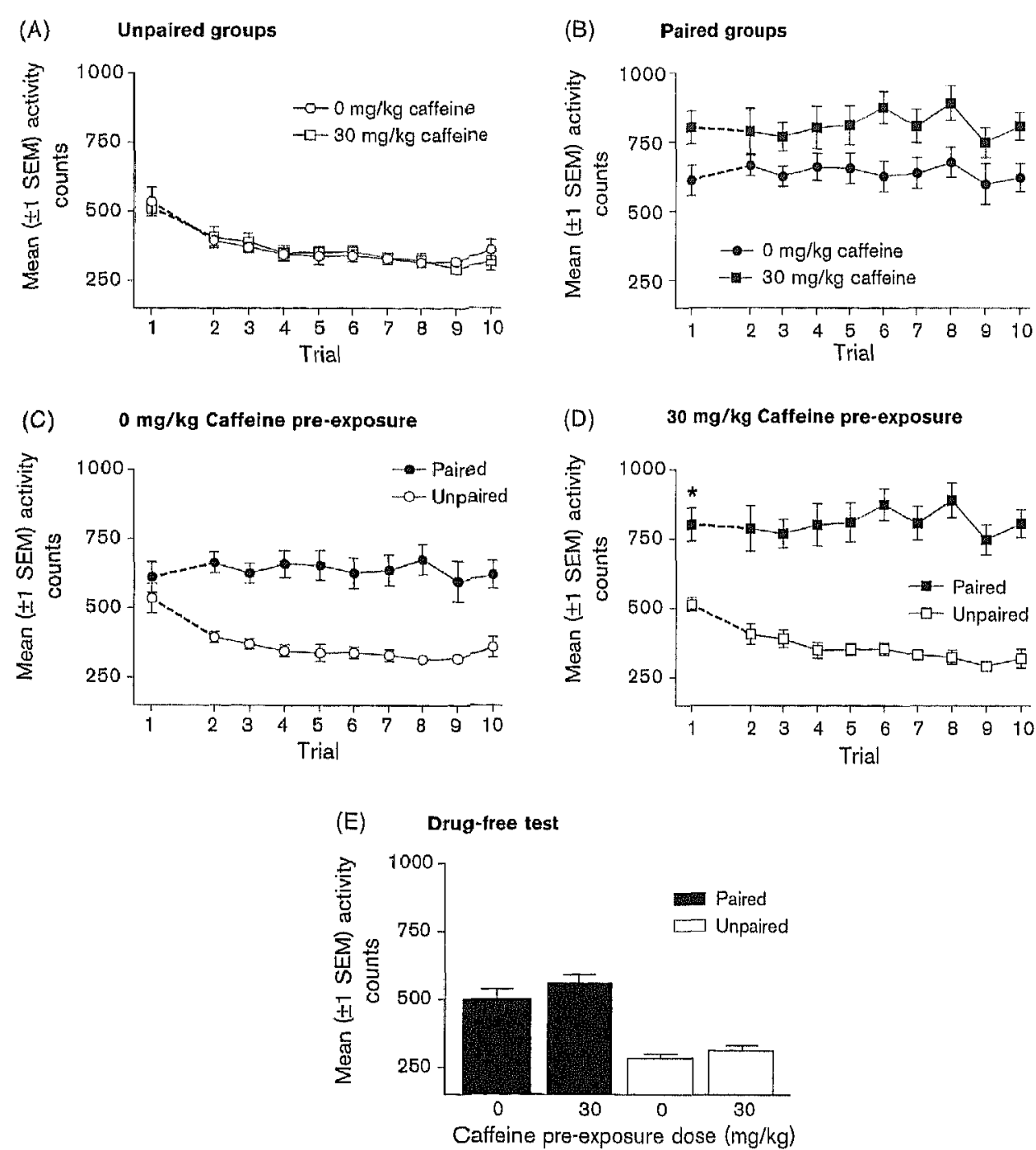

Locomotor activity for rats treated with $0.5 \mathrm{mg} / \mathrm{kg}$ amphetamine (Experiment 2). (A) and (B) contrast 0 versus $30 \mathrm{mg} / \mathrm{kg}$ caffeine pre-exposure for Unpaired and Paired groups, respectively. (C) and (D) contrast Paired versus Unpaired groups for rats pre-exposed to 0 and $30 \mathrm{mg} / \mathrm{kg}$ caffeine. (E) Activity data from the drug-free test for conditioning. *30 mg/kg pre-exposed Paired rats were more active than comparable Unpaired controls on Trial 1.

effect of Dose and the Group $\times$ Dose interaction indicates that pre-exposure to caffeine potentiated amphetamine-induced activity (i.e. only the pre-exposed Paired group). This enhancement in activity, relative to the comparable non-preexposed group, was consistent across trials.

\section{Drug-free test}

Figure $3 E$ illustrates data from the drug-free test for conditioning. Analyses of these data revealed a main effect of Group $[F(1,35)=77.97, P<0.001]$, indicating conditioned hyperactivity in Paired rats. The main effect of Dose $[F(1,35)=2.62]$ and the Group $\times$ Dose interaction $[F<1]$ were not significant.

\section{Discussion}

Although caffeine can be a potent anorexic (see Gans, 1984), there were no significant differences in weight between rats pre-exposed to caffeine and those preexposed to saline in the present work. Caffeine preexposure did not have any non-specific effects on initial activity in a novel environment or habituation (decrease in activity) over trials, in Unpaired rats. Thus, differences in activity after chronic caffeine exposure cannot be attributed to non-specific effects on weight, environmental familiarization, or general motor activity.

Depending on the situation, nicotine produces locomotor suppression in rats; this suppression is replaced with 
enhanced activity after repeated nicotine treatment (e.g, Clarke and Kumar, 1983; Kita et al., 1992; Ksir, 1994; Bevins et al., 2001). We replicated this pattern of activity in controls, and found that the general biphasic locomotor effects of nicotine were still present after pre-exposure to caffeine. Calfeine pre-exposure did not affect acute activity induced by 0.421 or $0.175 \mathrm{mg} / \mathrm{kg}$ nicorine (i.e. first conditioning trial for Paired rats). This outcome appears to contrast with previous caffeine pre-exposure research demonstrating enhanced hyperactivity after an acute nicotine challenge (Gasior $e t a l, 2000)$. In that study, rats were injected s.c. with nicotine $(0.3$ or $0.56 \mathrm{mg} / \mathrm{kg}$ salt; 0.105 or $0.196 \mathrm{mg} / \mathrm{kg}$ expressed as base, respectively), after which activity was monitored for $60 \mathrm{~min}$. However, due to the procedural restrictions of equating activity tests with nicotine discrimination tests, activity for the first $15 \mathrm{~min}$ was not included in the analyses of that study. In contrase, we cxamined the effects of nicotine immediately after administration and for only $30 \mathrm{~min}$. More importantly, Gasior et al. (2000) did not suspend caffeine exposure before the nicotine challenge test; rats had free access to caffeine in the home cage until just before the nicotine challenge. 'This manipulation opens the possibility that the acute psychomotor effect was due to the presence of boch drugs at the time of testing. Further evidence for this possibility has recently been published. In a similar nicotine-discrimination study, Gasior et al. (2002) demonstrated that, regardless of the chronic exposure condition (i.e. caffeine-water or tap-water), pretreatment with an i.p. injection of caffeine $(10,17$ or $30 \mathrm{mg} / \mathrm{kg}$ ) enhanced generalization to a 'threshold' dose of nicotine (i.e. $0.05 \mathrm{mg} / \mathrm{kg}$ base). This finding clearly indicates that the co-presence of nicotine and caffeine can have important behavioral effects. Whether differences in testing proto$\mathrm{col}$, or other procedural variations, such as nicotine dose, route of caffeine administration, or the co-presence of caffeine and nicotine in the rat at the time of testing, account for between-study differences will require further experimentation.

Caffeine enhances the psychomotor stimulant effects of amphetamine in an acute challenge (Gasior $e t a l ., 2000$ ). We confirmed this finding and extended it to include a chronic situation (i.e. repeated daily administration for 10 days). This outcome extends the literature demonstrating that chronic exposure to one drug of abuse can enhance the effects of another drug (e.g. Vezina et al., 1989; Vezina and Stewart, 1990; Kuribara, 1999; Xu and Domino, 1999).

Potentiation of amphetamine-induced locomotor activity by caffeine might reflect changes in the underlying neural processes common to both drugs. There is converging evidence that the psychomotor effects of caffeine are mediated by the same mesolimbic dopamine structures implicated in the psychomotor effects of amphetamine (e.g. Okada et al., 1996, 1997; Afanas'ev at al., 2000; Zahniser et $\mathrm{cl}, 2000$ ). One possibility is that pre-exposure to caffeine alters the mesolimbic dopamine (DA) system, such that it is more sensitive to amphetamine. For example, contralateral rotational behavior elicited by caffeine in rats with unilateral 6-hydroxydopamine lesions of the nigro-striatal pathway is attenuated by the $\mathrm{DA} \mathrm{D}_{2}$ receptor antagonist, eticlopride (Garrett and Holtzman, 1995). Also, the locomotor hyperactivity produced by caffeine in rats is attenuated by systemic administration of the DA $D_{1}$ receptor subtype antagonist SCH 23390 and the $\mathrm{DA}_{2}$ receptor subtype antagonists eticlopride and sulpiride (Garrett and Holtzman, 1994). These alterations might depend on the antagonistic interaction between adenosine and dopamine receptors (e.g. Ferté et al., 1992, see Fredholm et al., 1999 for a review). That is, adenosinergic antagonism by caffeine might disrupt inhibitory effects of endogenous adenosine on DA $D_{1}$ and $\mathrm{D}_{2}$ receptor affinity. However, the potential role for other neurotransmitter systems altered by chronic preexposure to caffeine should not be overlooked (e.g. Shi et al., 1994; Jacobson et al., 1996; Firedholm et al., 1999; see Daly, 1993 for a review).

Amphetamine-conditioned hyperactivity in a drug-free test was unaffected by caffeine pre-exposure, despite the enhancement of amphetamine-induced activity. Similarly, nicotine-conditioned hyperactivity was unaffected by caffeine pre-exposure. Clearly, much more parametric work is required before concluding that caffeine preexposure cannot retard or enlance an association between environmental cues and the psychomotor effects of ampletamine or nicotine. Such variables include amphetamine and nicotine doses, conditioning trial parameters (e.g. number of trials, trial duration, injection to placement interval), and pre-exposure parameters (administration route, inter-dose interval, dose, duration, etc.).

\section{Acknowledgements}

We chank Dawn Metschke for assistance in conducting this research and Joyce Besheer and Kartpagam Karthigeyan for their helpful comments on a previous version of this manuscript.

\section{References}

Afanas'ev I, Ferger B, Kuchinsky $K$ (2000). The associative type of sensitization to D-amphetamine is expressed as an NO-dependent dramatic increase in extracellular dopamine in the nucleus accumbens. Naunyn Schmiedeberg's Arch Pharmacol 362:232-237.

Ahmed SH, Oberling P, Di Scala G, Sandner G (1996). Amphetamine-induced conditioned activity does not result from a failure of rats to habituate to novelty. Psychopharmacology 123:325-332.

Arvanitogiannis A, Sullivan J, Amir S (2000). Time acts as a conditioned stimulus to control behavioral sensitization to amphetamine in rats. Neuroscience $101: 1-3$.

Bespelov AY, Zvartau EE (1996). Intraaccumbens administration of NMDA receptor antagonist $(+/-)$-CPP prevents locomotor activation conditioned 
by morphine and amphetamine in rats. Pharmacol Biochem Behav 55:203207.

Bevins RA, Besheer J, Fickett KS (2001). Nicotine-conditioned locomotor activity in rats: Dopaminergic and GABAergic influences on conditioned expression. Pharmacol Biochem Behav 68:135-145.

Bevins RA. Palmatier MI (2003) Nicotine-conditioned locomotor sensitization in rats: Assessment of the US-preexposure effect. Behav Brain Res (in press)

Beyer CE, Stafford D, LeSage $M G_{1}$, Glowa JR, Steketee JD (2001). Repeated exposure to inhaled toluene induces behavioral and neurochemical cross. sensitization to cocaine in rats. Psychopharmacology 154:198-204.

Browman KE, Badiani A, Robinson TE (1998). Modulatory effect of environmental stimuli on the susceptibility to amphetamine sensitization: A dose-effect study in rats. J Pharmacol Exp Ther 287:1007-1014.

Brown CR, Benowitz NL (1989). Caffeine and cigarette smoking: behavioral, cardiovascular, and metabolic interactions. Pharmacol Biochem Behav 34:565-570.

Cappel H, Poulos CX (1979). Associative factors in drug pretreatment effects on gustatory conditioning; Cross-drug effects. Psychopharmacology 64:209213.

Cauli $O$, Morelli M (2002). Subchronic caffeine administration senstitizes rats to the motor activating effects of dopamine $D(1)$ and $D(2)$ receptor agonists. Psychopharmacology 162:246-254.

Clark PBS, Kumar R (1983). The effects of nicotine on locomotor activity in tolerant and non-tolerant rats. $\mathrm{Br}$ J Pharmacol 78:329-337.

Cummings $\mathrm{KM}$, Jaén $\mathrm{CR}$, Giovino $\mathrm{G}$ (1985). Circumstances surrounding relapse in a group of recent exsmokers. Prev Med 14:195-202.

Daly JW (1993). Mechanism of action of caffeine. In: Grattini S (editor): Caffeine, Coffee, and Health. New York: Raven Press; pp. 97-150.

Fenu S, Cauli O, Morelli M (2000). Cross-sensitization between the motor activating effects of bromocriptine and caffeine: role of adenosine $\mathrm{A}(2 \mathrm{~A})$ receptors. Behav Brain Res 114:97-105.

Ferré $S$, Fuxe $K$, von Euler $G$, Johansson $B$, Fredholm B日 (1992). Adenosinedopamine interactions in the brain. Neuroscience 51:501-612.

Fraioli $S$, Crombag HS, Badiani A, Robinson TE (1999). Susceptibility to amphetamine-induced locomotor sensitization is modulated by environmenta stimuli. Neuropsychopharmacology 20:533-541.

Fredholm BB, Battig $K_{1}$ Holmen J, Nehlig A, Zvautau EE (1999). Actions of caffeine in the brain with special reference to factors that contribute lo its widespread use. Pharmacol Rev 51:83-133.

Gans JH (1984), Comparative toxicities of dietary caffeine and theobromine in the rat, Food Chem Toxicol 22,365-369.

Garrett BE, Holtzman SG (1994). D1 and D2 dopamine receptor antagonists block caffeine-induced stimulation of locomotor activity in rats. Pharmaco Biochem Behav 47:89-9.4

Garrett BE. Holtzman SG (†996). Does adenosine receptor blockade mediate caffeine-induced rotational behavior? I Pharmacol Exp Ther 274:207-214.

Gasior $M$, Jaszyna M, Peters J, Goldberg SR (2000). Changes in the ambulatory activity and discriminative stimulus effects of psychostimulant drugs in rats chronically exposed to caffeine: Effect of caffeine dose. J Pharmacol Exp Ther 295:1101-1111.

Gasior $M_{1}$ Jaszyna $M_{1}$ Munzer $P_{1}$ Witkin JM, Goldberg SR (2002). Caffeine potentiates the discriminative stimulus effects of nicotine in rats. Psycho pharmacology 162:385-395.

Istvan J, Matarazzo JD (1984). Tobacco, alcohol, and caffeine use: a review of their interrelationships. Psychol Bull 95:301-326.

Iwamoto ET, Williamson EC (1984). Nicotine-induced taste aversion: characterization and preexposure effects in rats. Pharmacol Biochem Behav 21:527532

Jacobson KA, von Lubitz DK, Daly JW, Fredholm $B B$ (1996). Adenosine receptor ligands: differences with acute versus chronic treatment. Trends Pharmacol Sci 17:108-113.

Kita $T$, Okamoto M, Nakashima $T$ (1992). Nicotine induced sensitization to ambulatory stimulank effect produced by daily administration into the ventral tegmental area and nucleus accumbens in rats. Life Sci 50:583-590.

Kozlowski LT, Henningfield JE, Keenan RM, Lei H, Leigh $G$, Jelinek LC, Pope MA, Haertzen CA (1993). Patterns of alcohol, cigarette, and caffeine and other drug use in two drug abusing populations. I Subst Abuse Treat 10:171-179.

Krall EA, Garvey AJ, Garcia RI (2002). Smoking relapse after 2 years of abstinence: findings from the VA Normative Aging Study. Nicotine Tob Res $4: 95-100$.

Ksir $\mathrm{C}$ (1994). Acute and chronic nicotine effects on measures of activity in rats: a multivariate analysis. Psychopharmacology 115:105-109.
Kunin D. Smith BR, Amit Z (1999). Nicotine and ethanol interaction on conditioned taste aversions induced by both drugs. Pharmacol Biochem Behav 62:215-221.

Kunin D, Latendresse MW, Gaskin S, Smith BR, Amit Z (2000). Preexposure effects of nicotine and acetaldehyde on conditioned taste aversion induced by both drugs. Pharmacol Biochem Behav 66:695-699.

Kuribara $H$ (1999). Does nicotine modify the psychotoxic effect of methamphetamine? Assessment in terms of locomotor sensitization in mice. $J$ Toxicol Sci 24:55-62.

Lamarque S, Taghzouti $K$, Simon $H$ (2001). Chronic treatment with Delta(9) tetrahydrocannabinol enhances the locomotor response to amphetamine and heroin: Implications for vulnerability to drug addiction. Neuropharmacology $41: 118-129$

Liguori $A_{1}$ Hughes JR, Goldberg $K$, Callas $P$ (1997). Subjective effects of ora caffeine in formerly cocaine-dependent humans. Drug Alcohol Depend 49:17-24.

Okada M, Mizuno K, Kaneko S (1996). Adenosine A1 and A2 receptors modulale extracellular dopamine levels in rat striatum. Neurosci Lett 212:53-56.

Okada M, Kiryu K, Kawata Y, Mizuno K, Wada K, Tasaki H, Kaneko S (1997) Determination of the effects of caffeine and carbamazepine on striatal dopamine release by in vivo microdialysis. Eur J Pharmacol 321:181-188.

Palmatier MI, Bevins RA (2001). Chronic caffeine exposure attenuates a subsequent nicotine conditioned taste avoidance in rats. Pharmacol Biochem Behav 70:279-289

Palmatier Ml, Bevins RA (2002). Examination of GABAergic and dopaminergic compounds in the acquisition of nicotine-conditioned hyperactivity in rats. Neuropsychobiology 45:87-94.

Pontieri FE, Monnazzi $P$, Scontrini A, Buttarelli FR, Patacchioli FR (2001) Behavioral sensitization to heroin by cannabinoid pretreatment in the rat. Eur J Pharmaco/ 421:R1-3.

Reid MS, Ho LB, Berger SP (1996). Effects of environmental conditioning on the development of nicotine sensitization: Behavioral and neurochemical analysis. Psychopharmacology 126:301-310.

Reid MS, Ho LB, Berger SP (1998). Behavioral and neurochemical components of nicotine sensitization following 15-day prelreatment: studies on contextual conditioning. Behav Pharmacol 9:137-148.

Schoffelmeer AN, De Vries TJ, Wardeh $G_{1}$ van de Ven HW, Vanderschuren LJ (2002). Psychostimulant-induced behavioral sensitization depends on nicotinic receptor activation. J Neurosci 22:3269-3276.

Shi D, Nikodijevic O, Jacobson KA, Daly JW (1994). Effects of chronic caffeine on adenosine, dopamine and acetylcholine systems in mice. Arch int Pharmacodyn Ther 328:261-287.

Shoaib M, Stolerman IP, Kumar RC (1994). Nicotine-induced place preferences following prior nicotine exposure in rats. Psychopharmacology 113:445452.

Shoaib M, Swanner LS, Yasar S, Goldberg SR (1999). Chronic caffeine exposure potentiates nicotine self-administration in rats. Psychopharmacology $142: 327-333$

Stewart J, Deschamps SE, Amir S (1994), Inhibition of nitric oxide synthase does not block the development of sensitization to the behavioral activating effects of amphetamine. Brain Res 641:141-144.

Stolerman IP, Fink $R$, Jarvik ME (1973). Acute and chronic tolerance to nicotine measured by activity in rats. Psychopharmacologia 30:329-342.

Stolerman IP, Garcha HS, Mirza NR (1995). Dissociations between the locomotor stimulant and depressant effects of nicotinic agonists in rats. Psychopharmacology 117:430-437.

Sutton MA, McGibney $K_{1}$ Beninger RJ (2000). Conditioned locomotion in rats following amphetamine infusion into the nucleus accumbens: blockade by coincident inhibition of protein kinase A. Behav Pharmacol 11:365-376.

Vezina $P$, Stewart J (1990). Amphetamine administered to the ventral tegmental area but not to the nucleus accumbens sensitizes rats to systemic morphine: Lack of conditioned effects. Brain Res 516:99-106.

Vezina $P_{1}$ Giovino AA, Wise RA, Stewart J (1989). Environment specific crosssensitization belween the locomotor activating effects of morphine and amphetamine. Pharmacol Biochem Behav 32:581-584.

$\mathrm{Xu} X$, Domino EF (1999). A further study on asymmetric cross-sensitization between MK-801 and phencyclidine-induced ambulatory activity. Pharmaco Biochem Behav 63:413-416.

Zahniser NR, Simosky JK, Mayfield RD, Negri CA, Hanania T, Larson GA, et al (2000). Functional uncoupling of adenosine $A(2 A)$ receptors and reduced response to caffeine in mice lacking dopamine D2 receptors. I Neurosci $20: 5949-5957$ 